\title{
RESOURCE-BASED ZONING MAP FOR SUSTAINABLE INDUSTRIAL DEVELOPMENT IN NORTH SINAI USING REMOTE SENSING AND MULTICRITERIA EVALUATION
}

\author{
H.A. EFFAT \\ Division of Environmental Studies and Land Use, \\ National Authority for Remote Sensing and Space Sciences, NARSS, Cairo, Egypt.
}

\begin{abstract}
Due to rapid urbanization in Egypt, the need for job creation and redistribution of population became a top priority for the Egyptian government. Creating infrastructure and new industrial zones in Sinai Peninsula can participate in solving the problem. Geographic Information System (GIS) and Spatial Multicriteria Evaluation (SMCE) have been widely used to analyze the land utilization based on the land's potentials and constraints. Using Shuttle Radar Topography Mission (SRTM) digital elevation model, meteorological data and various land use information, a holistic approach involving generation of thematic maps for two themes, natural resources theme and a least-cost theme, was adopted. Data such as accessibility, soil type, land cover, utilities and other ancillary information was employed to arrive at a locale-specific prescription for an industrial land use strategy. Analytical hierarchy process was conducted to investigate the resource-based suitability while minimizing cost of development using various spatial data. Expert knowledge was used to weigh factors within the natural resources theme based on three development objectives (scenarios). Running the weighted overlay model for each of the three objectives, three suitability index maps were produced. Potential sites for developing new industrial zones were identified based on the high suitability values for each scenario. Results highlight a good opportunity for developing the middle zones of Sinai (El Hassana and Nekhel divisions) in addition to the coastal belt.
\end{abstract}

Keywords: Egypt, GIS, multicriteria evaluation, natural resources, remote sensing, SRTM, zoning map.

\section{INTRODUCTION}

Land suitability analysis is the process of determining the fitness of a given tract of land for a defined use [1]. Land suitability assessment is a context-dependent, multicriteria evaluation of land capacity for development, based on the opinion of experts who define the most desirable factors and their optimal values and weights for this purpose $[2,3]$. Integration of information on natural resources, socio-economic and climatic conditions and other related ancillary information in a holistic manner for prescribing locale-specific intervention for a given area is very crucial. Geographic Information System (GIS) offers the capability of integrating spatial and attribute data and subsequent generation of action plan/developmental plan for sustainable development. Satellite images are useful source of land use/land cover information, along with GIS are used to gather, store, retrieve, analyze, display data related to land use/land cover, urbanization, and environment. Spatial Multicriteria Evaluation (SMCE) is a method for decision support. It provides an integrated assessment that can be defined as an interdisciplinary and participatory process of combining, interpreting and communicating knowledge from diverse scientific disciplines to allow a better understanding of complex phenomena. SMCE generally fits within a well-established framework. It utilizes the ability of GIS to represent a geographical area of interest in multiple dimensions. Each dimension is represented as a map layer, detailing the spatial variation of some variable (criteria). These map layers are then processed to provide information on how that particular criterion effects the overall decision. Each of the processed map layers is referred to as a 'suitability map'. Suitability maps are then combined with decisionmaker preferences according to the rules of the decision model on a cell-by-cell basis and an aggregated output generated. The resulting processed map may be thought as a locational alternative displayed according to its calculated suitability score. Multiple solutions may be found $[4,5]$. 
Suitability mapping of land using SMCE techniques have been broadly applied. Eastman [4] explains that in order to define the suitability of an area for a specific practice, several criteria need to be evaluated. It is defined [6] as the evaluation of a set of alternatives based on multiple criteria where the criteria are quantifiable indicators of the extent to which decision objectives are realized. Svoray et al. [7] incorporated habitat heterogeneity model with SMCE for the urban land-use allocation in a Mediterranean environment. Some experts took account of the economic factor in SMCE analysis. Turner et al. [8] combined economic valuation, integrated modeling, stakeholder analysis in MCE to provide a sustainable wetland management and policy. Afgan et al. [9] used the MCE to present an evaluation of the potential natural gas utilization in energy sector. Jiang [10] used SMCE in analysis of the suitable and low cost sites for industrial land use in Panzhihua, China. GIS enables computation of the criteria while a multicriteria decision analysis can be used to group them into a suitability index. Following a similar approach, Eastman et al. [11] produced a land suitability map for an industry near Kathmandu using IDRISI and Analytical Hierarchy Process (AHP) [12].

\subsection{Research objective}

North Sinai is chosen for this application due to three main reasons: first the region is rich in mineral resources, potential solar and wind energy in addition to a long coastal belt. Second, the desert nature and low populated cities of the peninsula highlights its need for further scientific researches that could unveil its potentials and hidden resources. Third, developing industrial zones is considered a backbone for job-creation and population attraction. Identification of potential zones for creating new industrial activities while considering the sensitive zones is the main objective and is believed to be a first step towards developing the region.

\subsection{Description of the study area}

Sinai is a triangular peninsula covering an area of $61,000 \mathrm{sq} \mathrm{km}$ in the North East of Egypt and joining the great continental land masses of Africa and Asia within the geographic location falling between latitudes $27^{\circ} 43^{\prime}$ and $31^{\circ} 19^{\prime}$ North and $32^{\circ} 19^{\prime}$ and $34^{\circ} 54^{\prime}$ East (Fig. 1a). The Peninsula is situated between the Gulf of Aqaba and Gulf of Suez, and is bounded from north by the Mediterranean Sea.
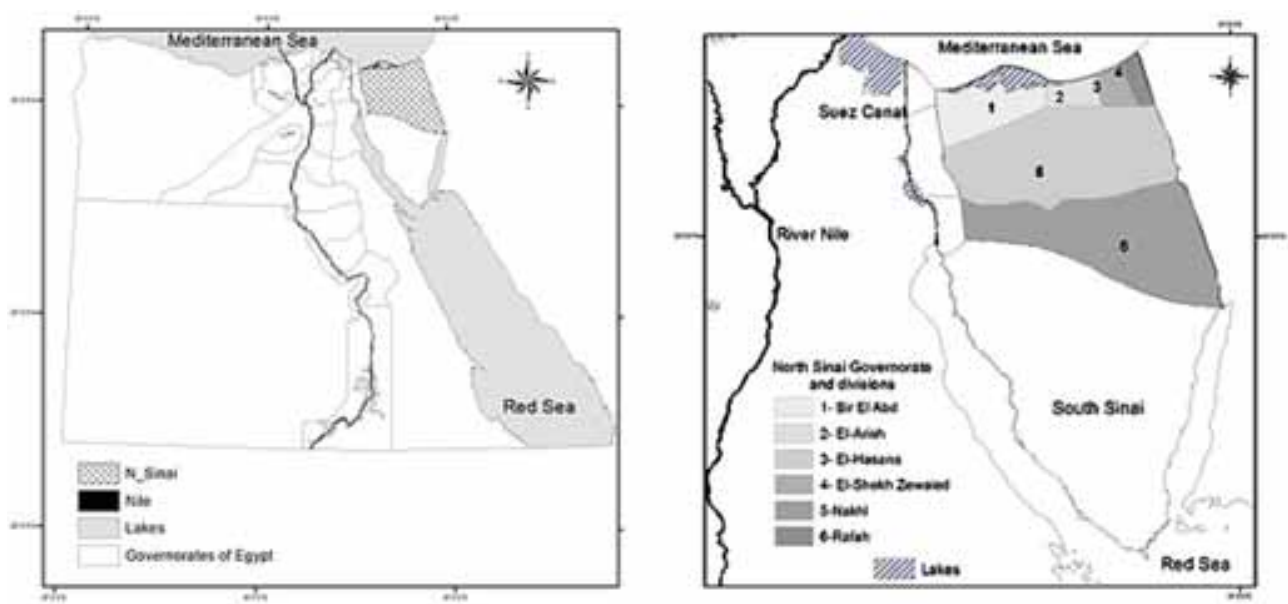

Figure 1: (a) Location of the Sinai Peninsula. (b) Administrative divisions of North Sinai. 
It is divided into two governorates, North Sinai and South Sinai governorates (Fig. 1b). The physical geography includes desert plains, sand dunes and sea coasts. The Mediterranean Sea borders the Peninsula from the North with a shoreline reaching $205 \mathrm{~km}$. North Sinai is divided into six administrative divisions and has eight cities which are low in population densities. The region is rich in mines and quarry sites, where kaolin, manganese, zircon, coal, feldspar and albitite along with quarrying activates such as gypsum, glass sand, perlato, marble, granite, dolomite and limestone are being extracted [13]. According to the World Bank, Egypt has some of the world's best wind power resources, especially in the Gulf of Suez area. Average wind speeds in the Gulf of Suez are estimated to reach $10 \mathrm{~m} / \mathrm{s}$ [14].

\section{MATERIALS AND METHODS}

Shuttle Radar Topography Mission (STRM) data [15] is used for this study. The data is acquired by Space Shuttle Endeavour mission in 2001 by C-band SAR interferometry instrument. These data cover approximately $80 \%$ of the total Earth surface. The original resolution of the data is 1 arcsec and for areas outside the US the 3-arcsec data are freely available that represent approximately a 90-m resolution. The available 3-arcsec data in the WGS84 geographic coordinate system were projected to UTM and resampled to $100-\mathrm{m}$ resolution. The data was used to derive the elevation, slope and area solar radiation map. SPOT-4 imageries [16], FAO Africover data [17] were used to derive the land use/land cover map. In addition, the topographic maps of Sinai scale 1:250,000 [18] were used to digitize the road network and utilities and updated from SPOT-4 4 images. The geological map produced by the Egyptian General Petroleum Corporation [19] was used to digitize some of the mines and quarries. Ground water depth was obtained from the hydro-geological map of Egypt [20]. Wind speed map Mortensen et al. [21] for Sinai was used. Annual area solar radiation was calculated using SRTM digital elevation model [15] in ESRI Spatial Analyst solar module [22]. A geographic database for North Sinai was established using ESRI Arc Map [23]. A conceptual flow chart describes the methodology as shown in Fig. 2.

\subsection{Identifying the resource-based suitability criteria}

Site selection using SMCE requires the creation of a set of suitability (factor maps). This study aims at producing a resource-based zoning map. Therefore, the existing potential resources are the main factors for selection of suitable sites for sustainable industrial development zones. Based on such objective, the following factors were selected and the factors maps were produced.

\subsubsection{Meteorological factors}

Energy is the backbone for any industrial activity. Renewable green energy is a future promise that can provide a sustainable development for a vast desert zone.

\subsubsection{Solar radiation map}

Suri and Hofierka [24] applied the Solar Analyst ArcG 9.2 extension, which can be used for ecological and biological applications. The solar radiation analysis tools, in ArcGIS Spatial Analyst extension was used for this analysis. Time configuration was set for the whole year option with a starting year 2011. Total radiation is calculated as the sum of the direct and diffuse radiation. Using the area solar radiation analysis, the global insolation (direct + diffuse, $\mathrm{Wh} / \mathrm{m}^{2}$ ) has been calculated for the entire study area showing where the highest amounts of radiation are. The solar radiation tool takes into account slope, hill shade, and aspect in order to produce an output which displays a cellby-cell breakdown of the estimated incoming radiation. The resultant area solar map was resampled to a $100-\mathrm{m}$ cell size to comply with the various raster images used in this study. 


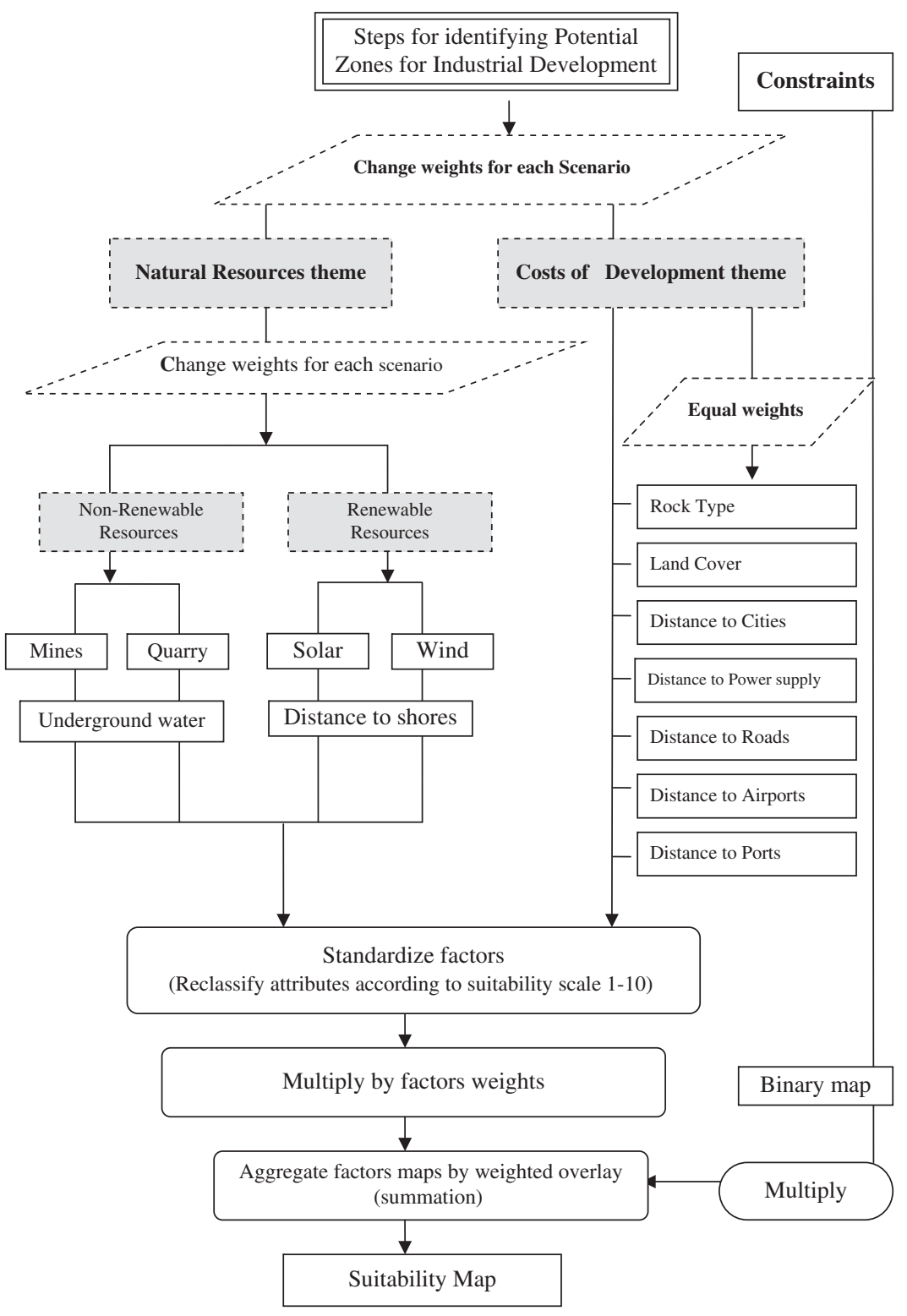

Figure 2: Conceptual diagram for the methodology.

\subsubsection{Wind speed map}

Wind energy map by Mortensen et al. [21] classifies the wind speed ranges in zones. Such map was considered a factor map for potential zones for industrial development. It was converted to raster, standardized and used as an input to the multicriteria model.

\subsubsection{Mineral resources}

The availability of mines or quarries is an essential factor for industrial activities. North Sinai encounters several occurrences of various types of mineral resources including: coal, black sands, 
glass sand, kaolin, as well as marl, dolomite, sand, gravel and sands. Large amount of raw materials for cement industry (limestone, shale and gypsum) are also available [13].

\subsubsection{Water resources}

Groundwater is one of the most important natural resources for the development in such areas of severe aridity as North Sinai. There are two main types of groundwater; the quaternary aquifer in wadi alluvium and coastal sand dunes, and the deep fracture zone aquifers in lower cretaceous sandstone formations. The underground water aquifers were scanned and digitized from the hydro-geological map of Sinai. The water depth contours were interpolated into an ESRI raster grid which was recoded according to the water depth into a suitability scale.

\subsubsection{Marine resources}

The proximity to a sea shoreline is an economic factor for industrial development. Shorelines habitat ports and harbors, and provide marine-based industry. In addition, sea water can be desalinated and provide the water needs of urban communities. The shoreline was traced from SPOT-4 images [16], saved as a feature class, and a distance function was used to create a distance to shore map.

\subsection{Identifying the criteria influencing costs of development}

\subsubsection{Soil map}

The soil map of North Sinai was used to ensure the preservation of soils that are suitable for agriculture and land reclamation.

\subsubsection{Land cover map}

FAO Africover land cover map [17] was updated using SPOT-4 image [16] and used to produce the land cover map. Cultivated lands, natural vegetation, water bodies, sabkha wetlands, sand dunes, urban areas and desert bare lands are the main land cover features of North Sinai.

\subsubsection{Distance to ports}

The proximity to existing ports is an economic factor for establishing an industrial zoning map. A distance function was used to create a distance to port's map.

\subsubsection{Distance to cities}

Due to the vast desert areas, the proximity of an industrial site to an urban settlement is an essential economic factor. Urban areas are the resource for manpower, suppler of the basic services and provider of market places. Therefore, the cities were digitized from the topographic map and the 'distance to cities' map was created.

\subsubsection{Distance to roads}

Roads are the main arteries for a development site. They provide accessibility and link remote areas, constituting a main factor for an industrial activity. In North Sinai Governorate, paved asphalted roads, gravelly soil roads, dusty-desert tracks exist. All roads were digitized from the topographic map, updated from SPOT-4 images [16] and a 'distance from roads' map was created.

\subsubsection{Distance to airports}

Airports are crucial in serving an industrial site providing accessibility and linking its remote areas. The airports were digitized from the topographic map and a distance map was created. 
2.2.7 Existing power supply utilities

The proximity of the site to a power supply facility such as high electric lines or power stations is an economic factor. The high electric lines and power stations were mapped from the topographic map, saved as a feature class.

\subsection{Creating the constraint map}

A constraint map was produced by masking out sensitive zones that should not be included in the developable lands. A binary image was created for each criterion by giving a zero value to the constraint and its buffer, while the rest of the region is given a value of one. The final constraints map was combined by multiplication. The constraint layers are described as follows:

\subsubsection{National protectorates}

North Sinai has unique protectorates. Zaraniq Protectorate represents an important wetland habitat within the Mediterranean Sea basin covering an area of $250 \mathrm{sq} \mathrm{km}$. The protectorate receives several migrating birds from Asia and Europe in addition to some residing types of birds. Varieties of fauna, flora and fish species exist. The protectorate was considered a constraint.

\subsubsection{Sabkha and water bodies}

Sabkha and salt marshes surround Bardawil lake in the study region. Such zone was excluded from the analysis.

\subsubsection{Archaeological sites}

The region includes some important archaeological sites, such as the Paleolithic human habitation sites. The study of such sites can have a great impact on the understanding of the movement of Paleolithic man and culture through northern Egypt. In addition to some Ancient Egyptian sites, the Roman, Coptic and Islamic monuments in North Sinai can encourage historic tourism. A 1-km buffer zone was created around such sites for future tourism development.

\subsubsection{High stream orders}

The stream network was delineated using SRTM digital elevation model and ESRI ArcGIS 9.2 spatial analyst Hydrology module. High stream order was selected and a 200-m buffer was created. Such zones were considered a constraint to avoid flood hazard.

\subsubsection{Developed lands}

A 2-km buffer zone was created around the cities and $1 \mathrm{k}$ in case of villages. Such buffers are meant to ensure future urban growth. A 200-m buffer zone was created around the main highways. Such zones were considered constraints.

\subsection{Weighing, standardization and aggregation of the factor maps}

A pairwise comparison matrix by Saaty [12] was used to calculate the factor weights. The method involves the following steps: 1) calculate the sum of the values in each column; 2) divide each element in the matrix by its column sum; 3 ) compute the average of the elements in each row of the normalized matrix, divide the sum by the number of factors. These averages provide an estimate of the relative weights of the factors where consistency ratio should be less than 0.10 [10]. The expert knowledge can be obtained from literature review. The pairwise comparison matrix, 
developed by Saaty [25] in the context of a decision-making process known as the analytical hierarchy process, was used for deriving the relative weights for the factors and themes. The process is well explained by Saaty [12], Saaty [25], Eastman [26] where a verbal comparison of factors is converted to a constructed measuring scale. A decision-making group of experts were asked to compare the relative importance of each pair of factors at a time as shown in Tables 1, 2 and 3. For the cost of development theme, equal weights were assigned to the factors. Attributes upon which criteria are measured have different scales; this necessitates their standardization into a common constructed suitability scale. The standardization of factor maps was done using ESRI ArcGis9.2 Spatial Analyst reclassification function. A common suitability scale of 1-10 is used where 1 is the least suitable and 10 most suitable. Distance function is used to create multi-buffer maps which are classified and standardized to the suitability scale (Tables 4 and 5). An aggregation procedure brings together all the decision variables to produce an overall evaluation [5]. The simple additive weight method, known as the weighted linear combination, was used to combine the criteria [6]. This process is often used in site-suitability studies where several factors affect the suitability of a site (Esri, 1996). The GIS overlay process can be used to combine the factors and constraints in the form of a Weighted Linear Combination (WLC) process according to the following equation $[4,5]$

where:

$$
S=\Sigma\left(W_{i} \cdot X_{i}\right) * \Pi_{C j},
$$

$S=$ is the composite suitability score, $W=$ weights assigned to each factor, $X_{i}$ is the criterion score of factor $i, c_{j}$ is the criterion score of constraint $j$, $\Pi$ is the product of constraints (1-suitable, 0 -unsuitable).

A Weighted Linear Combination (WLC) model was run three times, once for each scenario. Three resultant suitability maps were produced as described in the following section.

\subsection{Developing a three scenario-based strategy}

A strategy for development consisting of three scenarios was created using spatial multicriteria evaluation weighted linear combination model. Each of the three scenarios consists of two themes (natural resources theme and least-cost theme). Based on expert knowledge, an objective was set for each scenario. In order to study the impacts of utilization patterns of the natural resources theme, equal weights were used for the factors inside the least-cost theme for the three scenarios. Changing the weights of the factors in the natural resources theme and changing the relative importance (weights) of the two themes (natural resources and least-cost themes), different scenarios were produced and visualized in the form of three suitability maps. Zones with the highest suitability values were selected for each scenario.

\subsubsection{First scenario (phase I)}

Our objective was to maximize the utilization of available mineral and water resources in the region and to minimize costs of development (transportation, energy, infra-structure costs). The natural resources were given less priority in the first scenario. This is because minimizing the costs of development was to be given first priority. The natural resources set consisted of geological resources, water resources, marine resources and green energy resources. Natural resources theme was established 30\% less important and the least-cost theme 70\% more important for control on expenditure. Equal weights were assigned to the least-cost theme factors. 


\subsubsection{Second scenario (phase II)}

Use of non-renewable resources (geological exploitation and underground water) holds more priority in this scenario. Increase in expenditures for improving infra-structure is a must, thus the costs of development are expected to increase. Start the use of renewable resources such as wind and solar energy with a less emphasis on cost reduction. The natural resources theme was given $50 \%$ and the least-cost theme also $50 \%$. Equal weights were assigned to the least-cost theme factors.

\subsubsection{Third scenario (phase III)}

Maximize the use of renewable resources (solar and wind energy production and sea water desalination) and rely on green energy. Costs of new development are expected to decrease in the third scenario due to a reliable infra-structure to be created in phase two. Minimize the use of nonrenewable resources such as geological resources and underground water. In the natural resources theme, green energy is given the highest weight followed by sea water desalination and marine resources. This phase is the objective for a long term development. The natural resources theme was given a weight of (70\% - more important) and the least-cost theme (30\% - less important). Equal weights were assigned to the least-cost theme factors.

Table 1: Pairwise comparison weight matrix for natural resources in scenario 1.

\begin{tabular}{lccccc}
\hline Scenario 1 & Geology & Hydrology & Marine & Green Energy & Weight \\
\hline Geology & 1 & 1 & 3 & 2 & 0.341 \\
Hydrology & 1 & 1 & 3 & 2 & 0.341 \\
Green Energy & $1 / 3$ & $1 / 3$ & 1 & $1 / 2$ & 0.105 \\
Marine & $2 / 3$ & $2 / 3$ & 2 & 1 & 0.210 \\
\hline
\end{tabular}

Table 2: Pairwise comparison weight matrix for natural resources in scenario 2.

\begin{tabular}{lccccc}
\hline Scenario 2 & Geology & Hydrology & Marine & Green Energy & Weight \\
\hline Geology & 1 & $5 / 3$ & $5 / 2$ & 5 & 0.452 \\
Hydrology & $3 / 5$ & 1 & $3 / 2$ & 3 & 0.272 \\
Marine & $2 / 5$ & $2 / 3$ & 1 & 2 & 0.180 \\
Green & $1 / 5$ & $1 / 3$ & $1 / 2$ & 1 & 0.090 \\
\hline
\end{tabular}

Table 3: Pairwise comparison weight matrix for natural resources in scenario 3.

\begin{tabular}{lccccc}
\hline Scenario 3 & Geology & Hydrology & Marine & Green Energy & Weight \\
\hline Geology & 1 & 2 & $2 / 3$ & $1 / 2$ & 0.212 \\
Hydrology & $1 / 2$ & 1 & $1 / 3$ & $1 / 4$ & 0.081 \\
Marine & $3 / 2$ & 3 & 1 & $3 / 4$ & 0.318 \\
Green Energy & 2 & 4 & $4 / 3$ & 1 & 0.425 \\
\hline
\end{tabular}




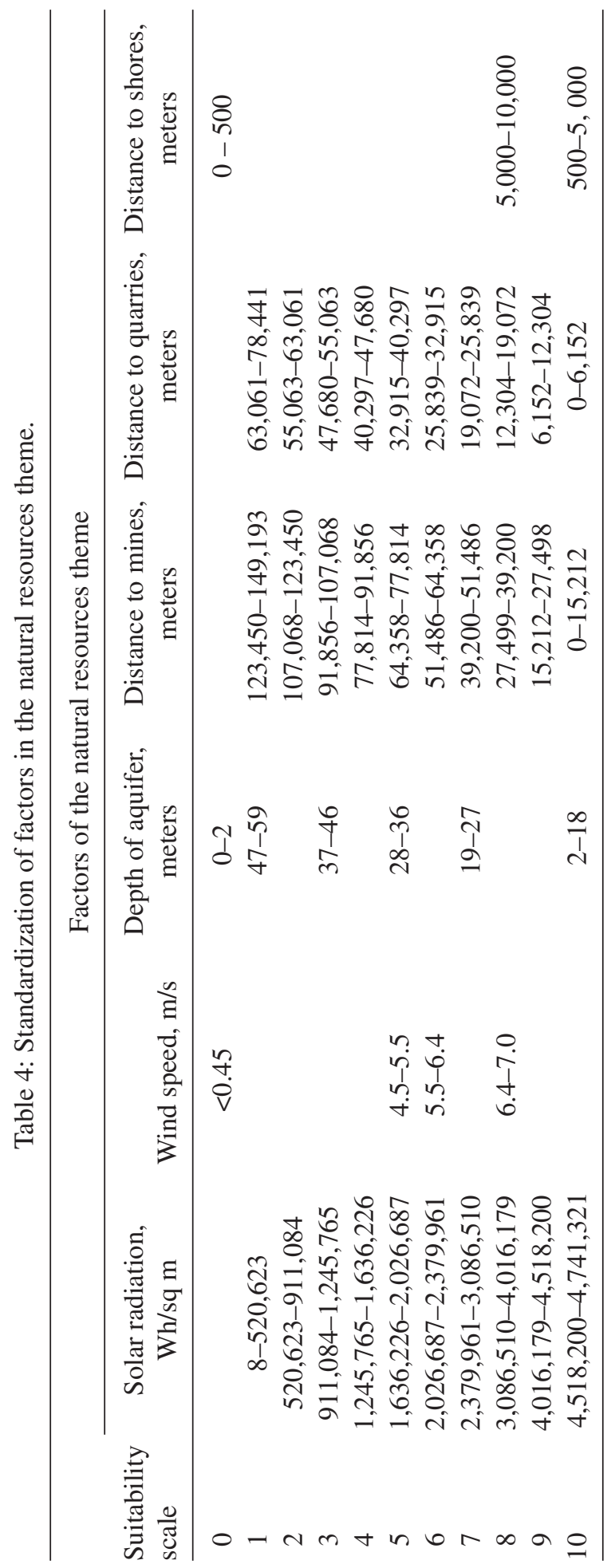




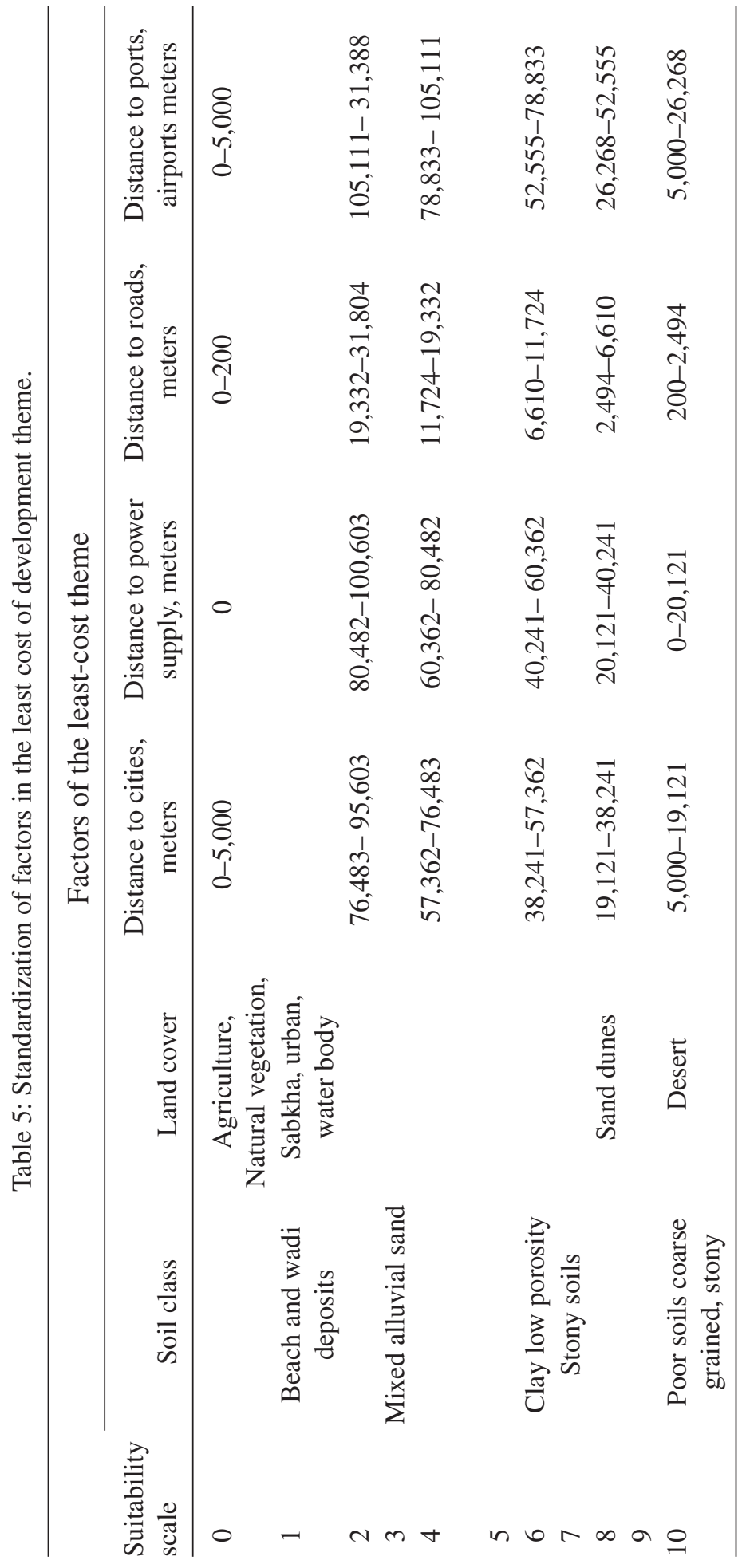




\section{RESULTS AND DISCUSSION}

Results of creating the factor maps and their suitability indices unveiled the distribution patterns of several parameters in the study region. The spatial distribution of natural resources in North Sinai is shown in the factor maps of the natural resources theme. Such factor maps are explained as follows (Fig. 3). The annual solar radiation received reaches 4,518,200-4,741,321 watt/hour/year (Fig. 3a) in some potential zones. For high potential zones for wind energy, the wind speed reaches $7 \mathrm{~m} / \mathrm{s}$. Wind
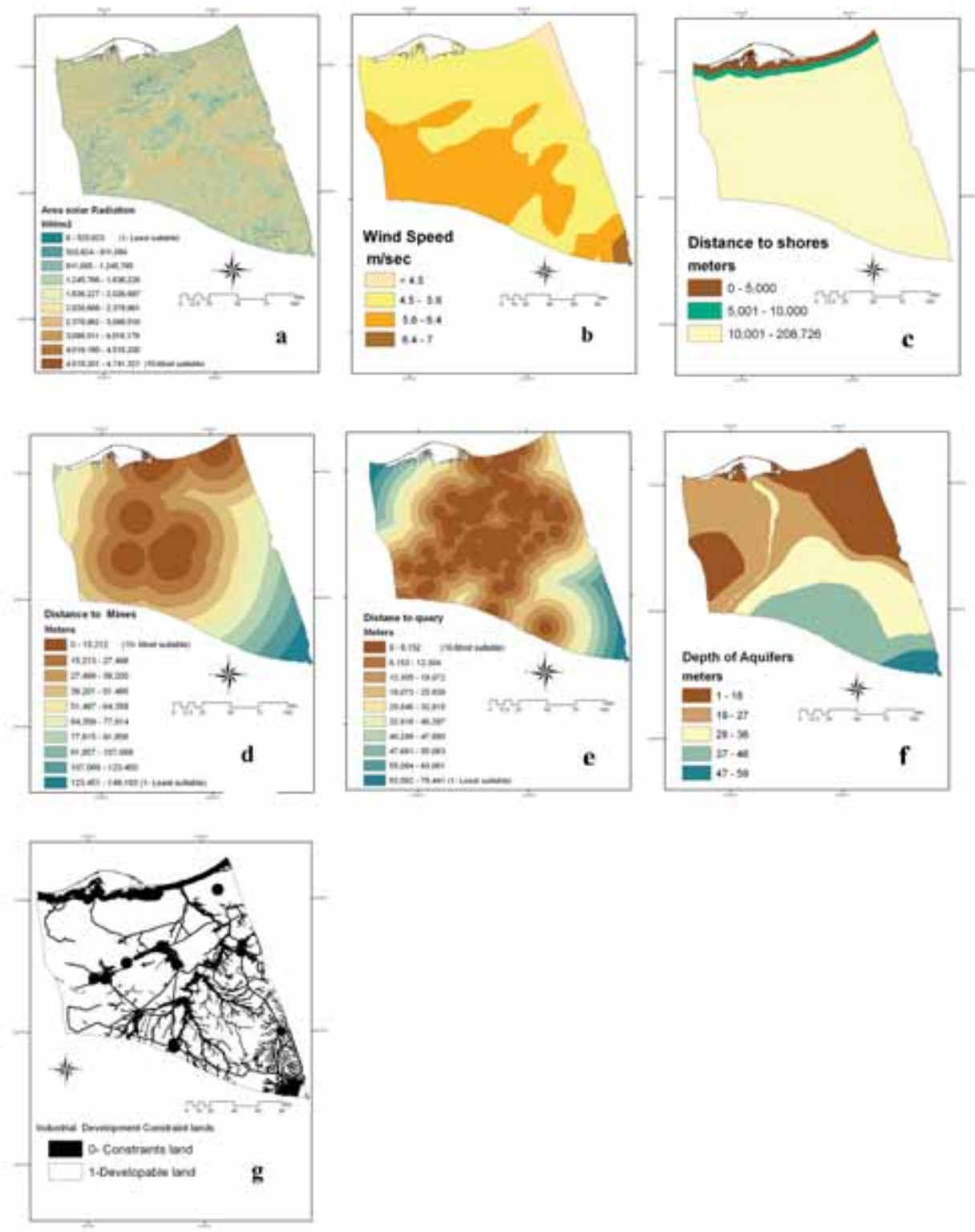

Figure 3: Criteria maps for the Natural Resources theme and constraints map; (a) Areas solar radiation (b) wind speed, (c) distance to shoreline, (d) distance to mines, (e) distance to quarries (f) depth of aquifers, and (g) combined constraints map. 
energy production can be produced starting $4.5 \mathrm{~m} / \mathrm{s}$ (Fig. 3b). Zones expressing the distance to shoreline are shown in (Fig. 3c). Mines and quarries are spread in the Northern and in the middle of the study region (Fig. 3d, e). Depth of the underground water varies. The range of depth is $1--50 \mathrm{~m}$ (Fig. 3f). The combined constraints map is shown in Fig. 3g.

In the results of examining the factor maps in the least-cost theme (Fig. 4), it is found that the soil classes range between clay with low porosity, stony soils, alluvial sands and poor soils, coarse, grained, stony and high steep slopes (Fig. 4a). The landcover map depicts the spread of large sand
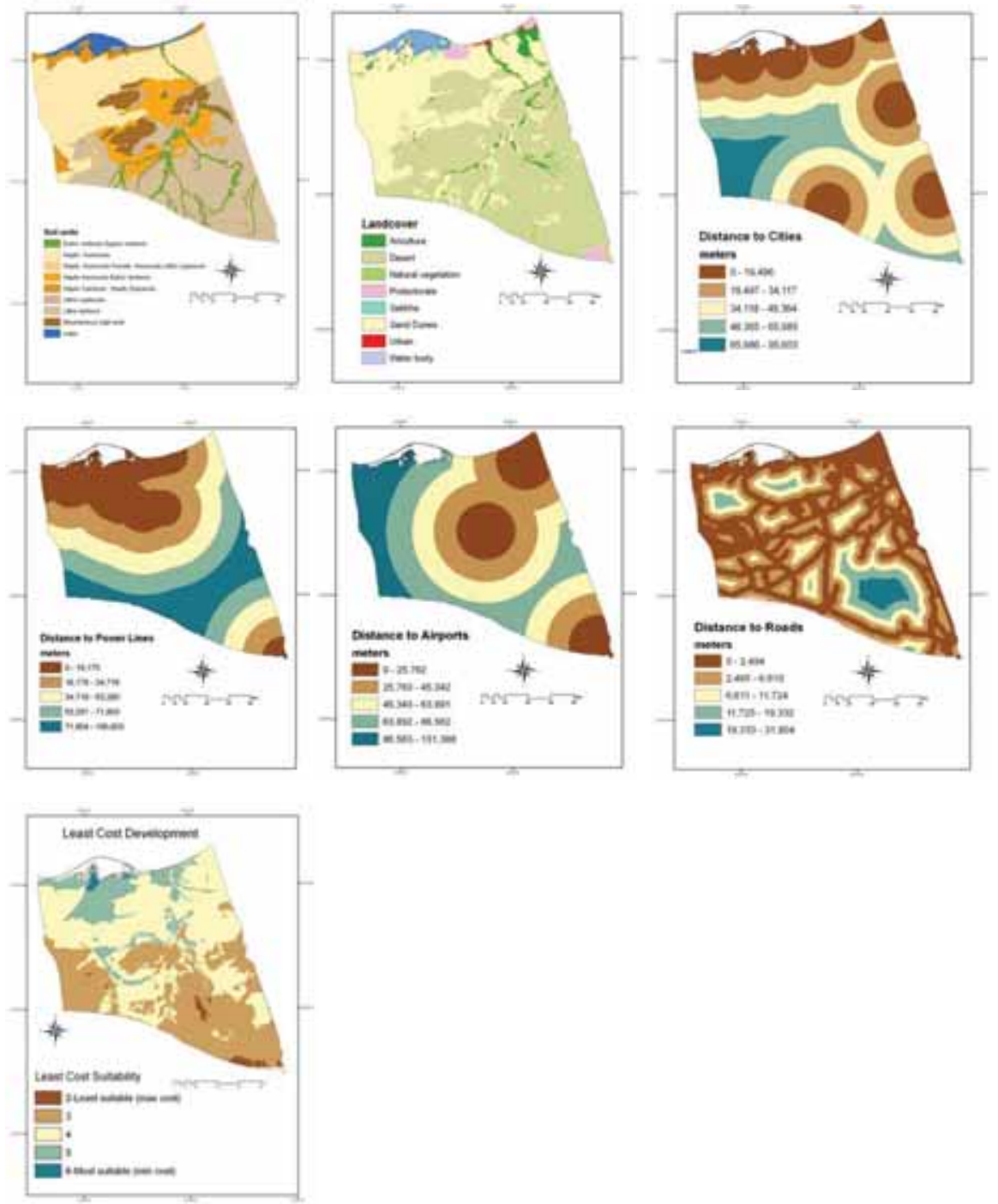

Figure 4: Criteria map for Least Cost of Development LCD theme: (a) Soil type, (b) land cover, (c) distance to cities, (d) distance to power supply, (e) distance to airports, (f) distance to roads, and (g) combined Least Cost of Development theme index map. 
dunes bodies in the region (Fig. 4b). Distances to cities, to power supply, airports and roads are shown in Fig. 4c, d, e and f, respectively. Aggregation of the least-cost factors is shown in Fig. 4g.

Running the SMCE in the three scenarios resulted in three suitability index maps (Fig. 5a-c). Zones of high suitability values were selected and mapped. Such zones are the most suitable for establishing industrial activities. Such zones are described in Table 6.

The results reveal that there is a great chance of developing large zones of industrial-based activities in North Sinai lands. In an area of around 3,763 sq km in the first Scenario, such development can be based on the existing natural resources (mineral resources) and with relatively limited expenditure, e.g. coal-based industry such as, glass, crystal, ceramics, iron; and coastal-based industry such as fisheries and extraction of salts. For the second scenario, there is a great chance for achieving a sustainable development for large amounts of lands (around 5,660 sq km). This is to be based on improving the existing infra-structure and relying partially on renewable energy (solar and wind energy) and creating new job opportunities. More potential zones are found in the middle zones of the study region. For the third scenario, an area of around 2,106 sq km is considered highly suitable. Such zones are distributed among the various administrative divisions in North Sinai. A good opportunity for developing the middle zones of Sinai (El Hassana and Nekhel divisions) exists in addition to suitable zones spreading along the coastal belt.

Table 6: Areas and spatial distribution of potential zones for industrial development.

\begin{tabular}{lccc}
\hline $\begin{array}{l}\text { Administrative } \\
\text { Divisions }\end{array}$ & $\begin{array}{c}\text { First scenario } \\
\text { Area sq km }\end{array}$ & $\begin{array}{c}\text { Second scenario } \\
\text { Area sq km }\end{array}$ & $\begin{array}{c}\text { Third scenario } \\
\text { Area sq km }\end{array}$ \\
\hline El Sheikh Zowaied & 139.49 & 285.67 & 88.96 \\
Rafah & 4.24 & 300.52 & 51.15 \\
El Arish & 301.84 & 83.74 & 100.52 \\
Beer El Abd & 947.29 & 696.56 & 313.85 \\
El Hasana & 1929.80 & 3337.0 & 807.80 \\
Nakhel & 440.84 & 956.38 & 743.43 \\
Total area & 3763.5 & 5659.87 & 2105.71 \\
\hline
\end{tabular}
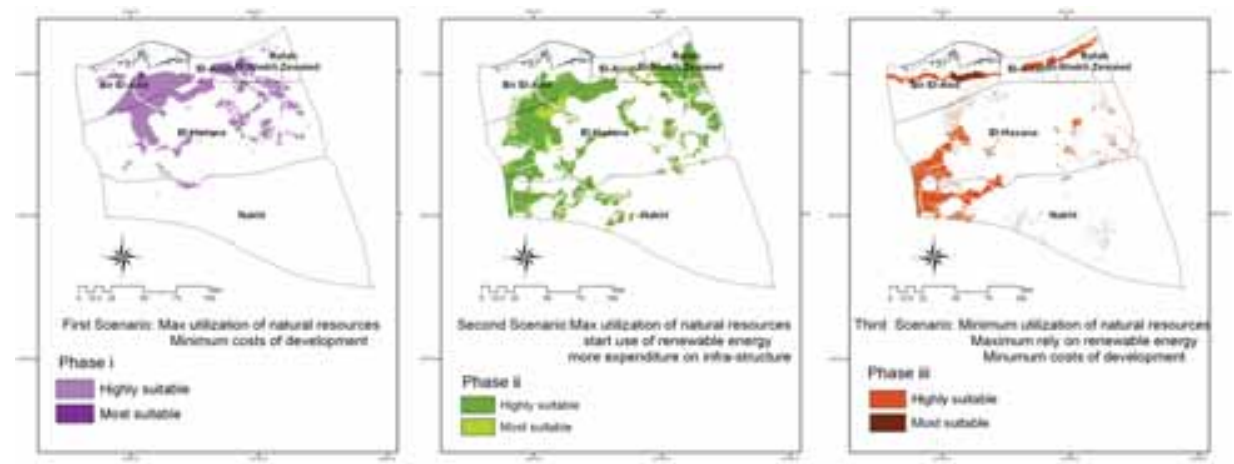

Figure 5: Comparison of the potential zones for the three industrial development scenarios using the multicriteria evaluation method: (a) First scenario, (b) Second scenario, and (c) Third scenario. 
It is also necessary to mention the advantages and limitations for the applied methodology as follows.

Integration of remotely sensed data with spatial multicriteria analysis can provide what-ifscenarios and several possibilities for achieving a goal. The technique is time-and-cost-saving and bridges the gap between decision makers and the public as the results can be discussed with the public through digital maps. The resultant suitability maps, combined with detailed studies and field investigations, are quite useful in strategic environmental assessment (SEA) analysis.

Spatial multicriteria analysis is good tool for decision making, yet, as a compilation of heterogeneous variables, results from such a technique does not much represent reality. In general, land use decisions are usually taken by multiple stakeholders; many arguments about the criteria attributes rating, weighting and the aspect of the decision making itself arise. Thus results are usually criticized as being subjective. So the SMCE technique is only a partial method for help in decision making and can be used as a guideline for land use decision making. In any case, it is a good tool to systematize the territorial distribution of the different variables involved and their implications. Also, this kind of models requires regular updates of the database. Fortunately, the flexibility of GIS-based analysis makes it easy to incorporate additional data layers and updates.

\section{CONCLUSION}

This study focuses on the necessity of adopting a holistic integrated approach that integrates land resources, potentials and constraints in the land-use decision strategies for achieving sustainable planning at a regional scale. Applying such techniques can be an initial step towards sustainability. It unveils the relationship between potential resources and vulnerable features that can be spatially competing, thus providing indicator maps as a guide for zoning and land-use strategies. Applying the spatial multicriteria evaluation and decision making in this study provided many possibilities to create scenarios (visions) based on a selected set of criteria for developing new industrial zones in North Sinai. Such visions are based on two themes; namely resources theme based on existing natural resources, and cost theme based on the existing infra-structure in the study region. Different priorities (weights) were given to the two themes and the factors constituting them. Accordingly, different scenarios or visions were produced using the SMCE model. Despite the uncertainty about data accuracy on such coarse scale analysis and possible future land use changes, the results obtained in this study show that the methodology is quite flexible and adaptable to the decision maker's objectives and alternatives.

\section{RECOMMENDATION}

Based on the output of this study, high suitability zones need to be studied and compared in more detailed scale, together with field investigation and environmental impact assessed. More studies in this field are needed especially in developing countries. It is highly recommended that the land-use decision makers adopt the SMCE technique. Such integrated approach is believed to overcome most of the shortcomings of the current planning practice resulting from lack of integrated data, integrated vision and evaluative scenarios in the land-use planning sectors.

\section{ACKNOWLEDGMENT}

This research was funded by the National Authority for Remote Sensing and Space Sciences, NARSS, Cairo, Egypt as a work package of an integrated project for establishing an information infrastructure for Decision Support System in Sinai Peninsula. 


\section{REFERENCES}

[1] Steiner, F., McSherry, L. \& Cohen, J., Land suitability analysis for the Upper Gila River Watershed. Landscape and Urban Planning, 50, pp. 199-214, 2000. doi: http://dx.doi. org/10.1016/S0169-2046(00)00093-1

[2] Jiang, H. \& Eastman, R., Application of fuzzy measures in multi-criteria evaluation in GIS. International Journal of Geographic Information Science, 14, pp. 173-184, 2000. doi: http:// dx.doi.org/10.1080/136588100240903

[3] Stoms, D., McDonald, J.M. \& Davis, F.W., Fuzzy assessment of land suitability for scientific research reserves. Environmental Management, 29, pp. 545-558, 2002. doi: http://dx.doi. org/10.1007/s00267-001-0004-4

[4] Eastman, J.R., Jin, W., Kyem, P.A.K. \& Toledano, J., Raster procedures for muli-criteria/multiobjective decisions. Photogrammetric Engineering \& Remote Sensing, 61(5), pp. 539-547, 1995.

[5] Bailey, D.T., Development of an Optimal spatial decision-making using approximate reasoning, Doctor of Philosophy thesis submitted to Faculty of Built Environment and Engineering. Queensland University of Technology, 2005.

[6] Malczewski, J., GIS and Multicriteria Decision Analysis, John Wiley: New York, pp. 182-187, 1999.

[7] Svoray, T., Bar, P. \& Bannet, T., Urban land-use allocation in a mediterranean ecotone; habitat heterogeneity model incorporated in a GIS using a multi-criteria mechanism. Landscape and Urban Planning, 72, pp. 337-351, 2005. doi: http://dx.doi.org/10.1016/j.landurbplan.2004.05.001

[8] Turner, R.K., Bergh, J.C.J.M., Soderqvist, T., Barendregt, A., Straaten, J., Maltby, E. \& Ierland, E.C., Landscape and institutional perspectives, ecological-economic analysis of Wetlands: scientific integration for management and policy. Ecological Economics, 35, pp. 7-23, 2000. doi: http://dx.doi.org/10.1016/S0921-8009(00)00164-6

[9] Afgan, N.H., Pilavachib, P.A. \& Carvalh, M.G., Multi-criteria evaluation of natural gas resources. Energy Policy, 35, pp. 704-713, 2007. doi: http://dx.doi.org/10.1016/j.enpol.2006.01.015

[10] Jiang, J., Analysis of the Suitable and Low-Cost Sites for Industrial Land Using Multi Criteria Evaluation: A Case of Panzhihua, China. Master's of Science thesis in Geoinformatics TRITA-GIT EX 07-010. School of Architecture and the Built Environment Royal Institute of Technology (KTH) 100 44: Stockholm, Sweden, 2007.

[11] Eastman, J.R., Kyem, P.A.K. \& Toledano, J., A procedure for multiobjective decision making in GIS under conditions of conflicting objectives. In Proceedings of European Conference on Geographical Information Systems, EGIS'93, EGIS Foundation, Utrecht, pp. 438-448, 1993.

[12] Saaty, T.L., The Analytic Hierarchy Process, McGraw-Hill: New York, pp. 20-25, 1980.

[13] Center of Housing and Building Researches, Ministry of Housing, Utilities and Urban Development, Egypt, Mines and quarry map of Egypt, 2007.

[14] Renewable Energy World.com: Renewable Energy News and Information on the Internet. Cited in 4 September 2012: http://www.renewableenergyworld.com/rea/news/article/2010/12/ quick-look-renewable-energy-d evelopment-in-egypt.

[15] Shutle Radar Topography Mission, United States Geological Survey (USGS), cited from: http://seamless.usgs.gov.

[16] French space agency CNES (Centre National d' etudes Spatiales), SPOT-4, 1998.

[17] Food and Agriculture Organization of the United Nations (FAO). Africover Landcover Web maps accessed 2005.

[18] Military of Survey Department, The Topographic Map of Egypt, scale 1:1000,000, 1995. 
[19] Egyptian General Petroleum Corporation, CONOCO-Coral, The geological map of Egypt, Scale 1:500,000, EGPC, Cairo, 1987.

[20] Research Institute for Groundwater (RIGW), National Water Research Center (NWRC). The hydro-geological map of Egypt, scale 1:200,000, 1999.

[21] Mortensen, N.G., Hansen, J.C., Badger, J., Jørgensen, B.H., Hasager, C.B., Georgy Youssef, L., Said Said, U., Abd El-Salam Moussa, A., Akmal Mahmoud, M., El Sayed Yousef, A., Mahmoud Awad, A., Abd-El Raheem Ahmed, M., Sayed, A.M., Hussein Korany, M. \& AbdEl Baky Tarad, M., Wind Atlas for Egypt, Measurements and Modeling 1991-2005. New and Renewable Energy Authority, Egyptian Meteorological Authority and Risø National Laboratory. ISBN 87-550-3493-4. 258 pp, 2005.

[22] ESRI Using ArcGIS 9.2 Spatial Analyst. Environmental System Research Institute Inc., Redlands, California, 2006.

[23] ESRI Arc Map, version 9.2, User Manual, ESRI, Redlands, California, 2006.

[24] Suri, M. \& Hofierka, J., A new GIS-based solar radiation model and its application to photovoltaic assessments. Transactions in GIS, 8, pp. 175-190, 2004. doi: http://dx.doi.org/ 10.1111/j.1467-9671.2004.00174.x

[25] Saaty, T.L., Scaling methods for priorities in hierarchal structures. Math Psychology, 15, pp. 234-281, 1977. doi: http://dx.doi.org/10.1016/0022-2496(77)90033-5

[26] Eastman, J.R., IDRISI Taiga. Guide to GIS and Image Processing. Clark University. Manual version 16.02, 2009. 